\title{
Effect of Rosemary Extracts on Stabilitiy of Sunflower Oil Used in Frying
}

\author{
Elfadil E. Babiker ${ }^{1 *}$, Fahad Y. Al-Juhaimi ${ }^{1}$, Ebru Sandal Tanrıverdi², \\ Mehmet Musa Özcan ${ }^{2 *}$, Isam A. Mohamed Ahmed ${ }^{1}$, Kashif Ghafoor ${ }^{1}$, and \\ Ibrahim A. Almusallam ${ }^{1}$

\footnotetext{
${ }^{1}$ Department of Food Science and Nutrition, College of Food and Agricultural Sciences, King Saud University, Riyadh-SAUDI ARABIA
} \\ ${ }^{2}$ Department of Food Engineering, Faculty of Agriculture, University of Selçuk, 42031 Konya, TURKEY
}

\begin{abstract}
The oxidative stability of sunflower oil containing rosemary essential oil and extracts in the oil during frying were followed by measuring peroxide value. Variation in the values of $L^{*}$ of the frying oil containing extract was less than that of frying oil containing essential oil. $a^{*}$-Value of the fried oil containing extract highly significant decreased. Increase in the value of $b^{*}$ of 1 . and 2 . frying oil with $0.5 \%$ rosemary essential oil was less. $b^{*}$ Value of the frying oils containing rosemary extract increased compared to $b^{*}$ values of frying oils containing essential oil. $b^{*}$ Value of the frying oil that the essential oil of rosemary added showed less increase than $b^{*}$ value of the frying oil that extract of rosemary. The viscosity values of frying oils containing rosemary extract changed between $30.3 \mathrm{mPas}$ (1. frying oil containing $0.5 \%$ extract) and $35.5 \mathrm{mPas}$ (2. frying oil containing $0.5 \%$ extract). In addition, free fatty acidity values of frying oils containing essential oil at $0.1,0.3$ and $0.5 \%$ levels ranged from $0.160 \%$ (1. frying oil containing $0.5 \%$ essential oil) to $0.320 \%$ (1. frying oil containing $0.3 \%$ essential oil). Peroxide values of frying oils containing rosemary extracts were determined between $12.84 \mathrm{meq} \mathrm{O}_{2} / \mathrm{kg}$ (1. frying oil containing $0.1 \%$ extract) and $28.98 \mathrm{meq} \mathrm{O}_{2} / \mathrm{kg}$ (2. frying oil containing $0.1 \%$ extract). Peroxide value of frying made with $0.3 \%$ the rosemary essential oil increased less than that of made with the raw sunflower oil (control) $(p<0.05)$. Whenever rosemary essential oil and rosemary extract compare, the essential oil seems to be more effective on the peroxide value of the frying oil. The essential oil of rosemary have been effected more from the extracts of rosemary on the oxidative stability of sunflower oil.
\end{abstract}

Key words: rosemary, antioxidant activity, peroxide value, acidity, color, frying, sunflower oil

\section{Introduction}

Frying is an important operation in food processing and preparation. Frying often involve the exposure of oils and fat to heat, air and moisture and these often result to reduction in oil quality, which in turn change the structure of triglycerides present in the oil ${ }^{1)}$. During the deep fat frying process, oils and fats in the presence of atmospheric oxygen and high temperatures are used over and over again and are subjected to the maximum oxidative and thermal effect ${ }^{2)}$. The oxygen in deep-fat frying reacts with oil. The rate of oxidative degradation reactions increases as the concentration of oxygen and free radicals increases ${ }^{3)}$. Oxidative degradation occurring fats and oils leads to the formation of unwanted taste and odor, the emergence of a large number of compounds harmful to human health, a decrease in nutritional value ${ }^{4)}$.
Fats and oils are often disposed off after use due to cumulation of oxidation products which may affect human health and nutritional value of food, apart from decreasing the sensory quality of fried foods. It is very essential to reduce wastage of used in deep-fat frying process. effective utilization of fats and oils is essential ${ }^{5}$. The oxidation reactions due to fatty acids may be inhibited by antioxidants from the fried substrate, such as tocopherols, sulphur compounds, ascorbic acid or phenolic substances, present in fried plant foods or added to animal foods with spices ${ }^{6,7)}$.

Artificial antioxidants have been used in food manufacturing, particularly in fats and fatty foods storage for many years $^{8)}$. Synthetic antioxidants commonly used in food systems include butylated hydroxytoluene(BHT), butylated hydroxyanisole (BHA) and tertiary butylhydroquinone $(\mathrm{TBHQ})^{9,10)}$. However, the use of artificial antioxidants in

\footnotetext{
*Correspondence to: Mehmet Musa Özcan, Department of Food Engineering, Faculty of Agriculture, University of Selçuk, 42031 Konya, TURKEY; Elfadil E. Babiker, Department of Food Science and Nutrition, College of Food and Agricultural Sciences, King Saud University, Riyadh-SAUDI ARABIA

E-mail: mozcan@selcuk.edu.tr (MMÖ); ebabiker.c@ksu.edu.sa (EEB)

Accepted April 28, 2020 (received for review March 7, 2020)
}

Journal of Oleo Science ISSN 1345-8957 print / ISSN 1347-3352 online

http://www.jstage.jst.go.jp/browse/jos/ http://mc.manusriptcentral.com/jjocs 
food products have raised many safety concerns particularly because of their potential carcinogenic and teratogenic effects ${ }^{9}$. The use of tertiary butylhydroquinone in foods have been banned in many countries because of its detrimental effects in humans ${ }^{8}$. Consumers generally now prefer natural antioxidants to synthetic ones. In other to improve and preserve the sensory and organoleptic properties of food, natural antioxidants from spices and certain plants are now commonly used and their usage in food system is now popular and widely accepted by consum$\operatorname{ers}^{10)}$.

Various researches have been conducted on the oxidation inhibition properties of certain spices ${ }^{1)}$. The most extensively studied natural antioxidants are rosemary and sage $^{8}$. Among spices, rosemary have been found to contain highest amount of natural antioxidant and the cultivar (Rosmarinus officinalis L.) have been reported to contain highest antioxidant ability. The strong antioxidant ability of rosemary has been attributed to the presence of phenolic diterpenes such as rosmanol, carnosol, carnosic acid, isorosmanol and epirosmanol ${ }^{1)}$. The oxidative inhibitory properties of rosemary extract of about $0.02 \%$ on stability of sunflower oil at various temperatures have been report$\mathrm{ed}^{11}$. This present study was conducted to study the antioxidant action of essential oil and extracts of rosemary on the stability of sunflower oil during deep-frying.

\section{Materials and Methods \\ 2.1 Materials}

Rosemary were obtained from the local spice seller of Konya and were stored in a cool environment, until used for analysis. As for oil, refined sunflower oil was used. Potatoes that used frying were obtained from the local supermarket. All solvents used were of analytical grade. Acetic acid, ether, ethanol, potassium hydroxide, potassium iodide phenolplthalein, sodium thjiosulfate and starch solution were obtained from the essential oils and the edible oils analysis lab of the Food Engineering, Agricultural Faculty, Selçuk University, Konya.

\subsection{Methods}

2.2.1 Isolation of rosemary extract and essential oil

Rosemary was ground into flour with blender and $10 \mathrm{~g}$ $( \pm 0.5 \mathrm{~g})$ sample weighed and was put into $2 \times 250 \mathrm{~mL}$ erlenmayers and their mouths closed. With an interval of 20-30 minutes they are shaken, were stored overnight. Then, each one of all filtered from filter papers and ethanol extractions of spices were extracted with soxhlet device that tuned to $40^{\circ} \mathrm{C}$. The dried and milled rosemary plant (about $100 \mathrm{~g}$ for each) were subjected to hydrodistillation for $3 \mathrm{~h}$ using a Clevenger-type apparatus and the oils obtained were dried over anhydrous sodium sulfate.

\subsubsection{Deep fat frying process}

The fry-pan $(19 \times 3.5 \mathrm{~cm}$ in size, no cover $)$ was used for frying process. Oil sample was taken for comparison from the fry-pan. The essential oil and extract concentrations $(0.1 \%, 0.3 \%$ and $0.5 \%)$ of rosemary were used in the frying process. The fry-pan was put for frying process on the electric heater. Oil $(220 \mathrm{~mL})$ was introduced into a fry-pan before adding extract or essential oil. The potatoes were peeled, washed, cut as uniformly as possible, wiped, weighed ( $\sim 53.5 \mathrm{~g})$ and introduced into frying oil immediately. Deep-fat frying was carried out for both extract and essential oil of $0.1 \%, 0.3 \%$ and $0.5 \%$, respectively, twice in same oil. Before each frying, fry-pan was cleaned. At the end of the frying process (the frying process takes 5-6 minutes), frying oil was filtered with filter paper and samples were taken for analysis. Oil samples taken fromwere stored in the refrigerator until analysis.

\subsubsection{Assessment of Instrumental Color}

Chromameter was used for colour analysis. A little oil was put into a clean petri and the colour value of three different regions was read. The average of the values that is read were noted. The oil colour was measured using a colorimeter (Minolta Chroma meter CR 400 (Minolta Co., Osaka, Japan) ) and CIELAB colorimetric system was applied. $20 \mathrm{~mL}$ of samples was carefully transferred into petri dish and liquid probe of the colorimeter was inserted into the dish to take the readings and CIE lab coordinate were recorded. The colour values were expressed as $L^{*}$ (brightness/darkness), $a^{*}$ (redness/greenness) and $b^{*}$ (yellowness/blueness) ${ }^{12,13)}$.

\subsubsection{Determination of viscosity of frying oil}

Viscosity of the oil was measured using viscometer. About $35-45 \mathrm{~mL}$ of oil sample was carefully introduced into the viscometer and the values were recorded as mPas.

2.2.5 Determination of $\%$ free fatty acid of frying oil

The oil samples were weighed to $5 \mathrm{~g}$ fat \pm 0.01 for determination of \% free fatty acid of frying oil, thawed in 100 $\mathrm{mL}$ ether. a few drops of phenolplthalein were added and were shaked. Finally, it titrated with $0.1 \mathrm{~N} \mathrm{KOH}$ (potassium hydroxide) solution, consumption was recorded ${ }^{14)}$. FFA\% were calculated according to the following formula.

\section{$\mathrm{FFA}(\%):(\mathrm{V} / \mathrm{m}) \times 2.8$}

$\mathrm{V}$ : consumed $\mathrm{KOH}$ solution, $\mathrm{mL}$

$\mathrm{m}$ : sample weight, $\mathrm{g}$

\subsubsection{Determination of peroxide value}

2-3 g oil sample was weighed into the erlenmayer flask. About $10 \mathrm{~mL}$ of chloroform, $15 \mathrm{~mL}$ acetic acid and $1 \mathrm{~mL}$ potassium iodide solution were added to the oil sample inside flask and the mixture was shaken. The flask was then corked and kept in a dark environment for $5 \mathrm{~min}$ circa. $75 \mathrm{ml}$ distilled water was then added and this was followed by addition of some drops of starch solution and sample was titrated with $0.02 \mathrm{~N}$ sodium thiosulfate ${ }^{14}$. Per- 


\section{Antioxidant Activity of Rosemary Extracts}

Table 1 Physico-chemical properties of sunflower oil Containing rosemary essential oil and extracts.

\begin{tabular}{|c|c|c|c|c|}
\hline & Colour & $\begin{array}{l}\text { Viscosity } \\
\text { (mPas) }\end{array}$ & $\begin{array}{l}\text { Free fatty acidity } \\
\qquad(\%)\end{array}$ & $\begin{array}{c}\text { Peroxide value } \\
\left(\text { meq } \mathrm{O}_{2} / \mathrm{Kg}\right)\end{array}$ \\
\hline Raw oil (Initial) & $\begin{array}{l}L: 47.06 \\
a^{\infty}:-0.13 \\
b^{\infty}: 1.83\end{array}$ & $36.9 \pm 0.17 * a$ & $0.336 \pm 0.007 \mathrm{a}$ & $6.78 \pm 0.9 \mathrm{c}$ \\
\hline Raw oil 1. frying (without essential oil and extract) & $\begin{array}{l}L: 56.94 \\
a^{\infty}:-0.54 \\
b^{\infty}: 2.41\end{array}$ & $33.7 \pm 0.09 \mathrm{~b}^{* *}$ & $0.223 \pm 0.003 b$ & $16.8 \pm 0.7 \mathrm{~b}$ \\
\hline Raw oil 2. frying (without essential oil and extract) & $\begin{array}{l}L: 51.68 \\
a^{\mathrm{\alpha}}:-0.56 \\
b^{\mathrm{a}}: 2.98\end{array}$ & $32.9 \pm 0.13 \mathrm{c}$ & $0.214 \pm 0.011 b$ & $24.75 \pm 1.2 \mathrm{a}$ \\
\hline $0.1 \%$ essential oil added 1. frying & $\begin{array}{l}L: 48.78 \\
a^{\infty}:-0.34 \\
b^{\infty}: 2.18\end{array}$ & $36.0 \pm 0.21 \mathrm{a}$ & $0.163 \pm 0.007 \mathrm{c}$ & $13.6 \pm 0.8 b$ \\
\hline $0.1 \%$ essential oil added 2 . frying & $\begin{array}{l}L: 52.66 \\
a^{\infty}:-0.74 \\
b^{\mathrm{a}}: 4.13\end{array}$ & $35.8 \pm 0.09 b$ & $0.278 \pm 0.013 b$ & $24.24 \pm 1.31 b$ \\
\hline $0.3 \%$ essential oil added 1 . frying & $\begin{array}{l}L: 55.20 \\
a^{\mathrm{\alpha}}:-0.38 \\
b^{\mathrm{\alpha}}: 2.46\end{array}$ & $32.9 \pm 0.08 \mathrm{c}$ & $0.320 \pm 0.021 \mathrm{a}$ & $14.0 \pm 0.13 \mathrm{c}$ \\
\hline $0.3 \%$ essential oil added 2 . frying & $\begin{array}{l}L: 51.72 \\
a^{\infty}:-0.03 \\
b^{\infty}: 2.54\end{array}$ & $34.7 \pm 0.07 b$ & $0.221 \pm 0.009 b$ & $28.13 \pm 0.08 \mathrm{a}$ \\
\hline $0.5 \%$ essential oil added 1 . frying & $\begin{array}{l}L: 51.07 \\
a^{\mathrm{\alpha}}:-0.19 \\
b^{\mathrm{a}}: 2.02\end{array}$ & $34.2 \pm 0.11 b$ & $0.160 \pm 0.006 \mathrm{c}$ & $14.15 \pm 0.17 \mathrm{c}$ \\
\hline $0.5 \%$ essential oil added 2. frying & $\begin{array}{l}L: 51.72 \\
a^{\mathrm{\alpha}}:-0.03 \\
b^{\mathrm{\alpha}}: 2.54\end{array}$ & $34.7 \pm 0.06 b$ & $0.221 \pm 0.015 b$ & $28.13 \pm 0.11 \mathrm{a}$ \\
\hline $0.1 \%$ extract added 1 . frying & $\begin{array}{l}L: 54.74 \\
a^{\infty}:-0.67 \\
b^{\infty}: 5.04\end{array}$ & $31.9 \pm 0.09 \mathrm{c}$ & $0.278 \pm 0.017 \mathrm{c}$ & $12.84 \pm 0.13 c$ \\
\hline $0.1 \%$ extract added 2. frying & $\begin{array}{l}L: 51.00 \\
a^{\mathrm{\alpha}}:-1.39 \\
b^{\mathrm{\alpha}}: 5.82\end{array}$ & $34.8 \pm 0.012 \mathrm{a}$ & $0.273 \pm 0.019 \mathrm{c}$ & $28.98 \pm 1.21 \mathrm{a}$ \\
\hline $0.3 \%$ extract added 1 . frying & $\begin{array}{l}L: 52.41 \\
a^{\mathrm{\alpha}}:-3.62 \\
b^{\mathrm{a}}: 13.11\end{array}$ & $33.2 \pm 0.13 b$ & $0.334 \pm 0.021 b$ & $16.73 \pm 0.37 \mathrm{c}$ \\
\hline $0.3 \%$ extract added 2. frying & $\begin{array}{l}L: 54.11 \\
a^{\mathrm{\infty}}:-4.03 \\
b^{\mathrm{e}}: 15.77\end{array}$ & $30.5 \pm 0.07 \mathrm{c}$ & $0.325 \pm 0.027 b$ & $25.0 \pm 1.13 b$ \\
\hline $0.5 \%$ extract added 1 . frying & $\begin{array}{l}L: 46.11 \\
a^{\infty}:-3.91 \\
b^{\infty}: 16.28\end{array}$ & $30.3 \pm 0.04 c$ & $0.441 \pm 0.021 \mathrm{a}$ & $13.93 \pm 0.18 \mathrm{c}$ \\
\hline $0.5 \%$ extract added 2. frying & $\begin{array}{l}L: 47.98 \\
a^{\mathrm{\infty}}:-2.96 \\
b^{\mathrm{\alpha}}: 14.51\end{array}$ & $35.5 \pm 0.07 \mathrm{a}$ & $0.380 \pm 0.017 b$ & $22.15 \pm 0.21 b$ \\
\hline
\end{tabular}

$*$ mean \pm standard deviation; **Values within each column followed by different letters are significantly different $(p<0.05)$ 
oxide value were calculated according to the following formula:

Peroxide value: $(\mathrm{V} / \mathrm{m}) \times 2$

$\mathrm{V}$ : used in titration sodium thiosulfate, $\mathrm{mL}$ m: sample weight, g

\subsection{Statistical analysis}

Completely randomized split block design was used and JMP version 9.0 (SAS Inst. Inc., Cary, N.C.U.S.A) was used for analysis of variance (ANOVA). All analyses were carried out three times and the results were given as mean \pm standard deviation (MSTAT C) ${ }^{15)}$.

\section{Results and Discussion}

Physico-chemical properties of raw and frying oils containing rosemary oil and extracts at $0.1,0.3$ and $0.5 \%$ concentrations are given in Table 1. While the viscosity values of frying oils containing rosemary essential oil at $0.1,0.3$ and $0.5 \%$ concentrations vary between $32.9 \mathrm{mPas}$ (2. frying oil containing $0.3 \%$ essential oil) and $36.0 \mathrm{mPas}$ (1. frying oil containing $0.1 \%$ essential oil), the viscosity values of frying oils containing rosemary extract changed between $30.3 \mathrm{mPas}$ (1. frying oil containing $0.5 \%$ extract) and 35.5 mPas (2. frying oil containing $0.5 \%$ extract). In addition, while free fatty acidity (FFA) values of frying oils containing essential oil at $0.1,0.3$ and $0.5 \%$ levels range from $0.160 \%$ (1. frying oil containing $0.5 \%$ essential oil) to $0.320 \%$ ( 1 . frying oil containing $0.3 \%$ essential oil), FFA contents of frying oils containing rosemary extract were determined between $0.273 \%$ (2. frying oil containing $0.1 \%$ extract) and $0.441 \%$ (1. frying oil containing $0.5 \%$ extract). Also, peroxide values of frying oils containing rosemary essential oils varied between 13.6 meq $\mathrm{O}_{2} / \mathrm{kg}$ ( 1 . frying containing $0.1 \%$ essential oil) and 28.13 meq $\mathrm{O}_{2} / \mathrm{kg}$ (2. frying oil containing 0.3 and $0.5 \%$ essential oils) while peroxide values of frying oils containing rosemary extracts are determined between 12.84 meq $\mathrm{O}_{2} / \mathrm{kg}$ ( 1 . frying oil containing $0.1 \%$ extract) and 28.98 meq $\mathrm{O}_{2} / \mathrm{kg}$ (2. frying oil containing $0.1 \%$ extract). As seen in Table 1, the peroxide values of the sunflower oils added with rosemary essential oil and extracts in all three concentrations were higher in second frying compared to raw oil and raw oil 1. and 2. frying results. This difference was more pronounced when peroxide results were compared with the raw oil result. While the FFA values of sunflower oil added with rosemary extract decreased in the second frying compared to the first frying, fluctuations in those who added essential oil were observed. Partial differences were observed when the viscosity values of frying oils added with essential oil and extract were compared with the raw sunflower oil value. The viscosity values of frying oils added with essential oil and extract were partially decreased.

As shown in Fig. 1(a), $L^{*}$ value of the frying oil containing $0.5 \%$ extract of rosemary was very close to $L^{*}$ value of the raw oil. Variation in the values of $L^{*}$ of the frying oil containing extract was less than that of frying oil containing essential oil. The value of $a^{*}$ of the fried oil containing essential oil did not more increase (Fig. 2(a)). But, $a^{*}$-value of the fried oil containing extract highly significant de- a)

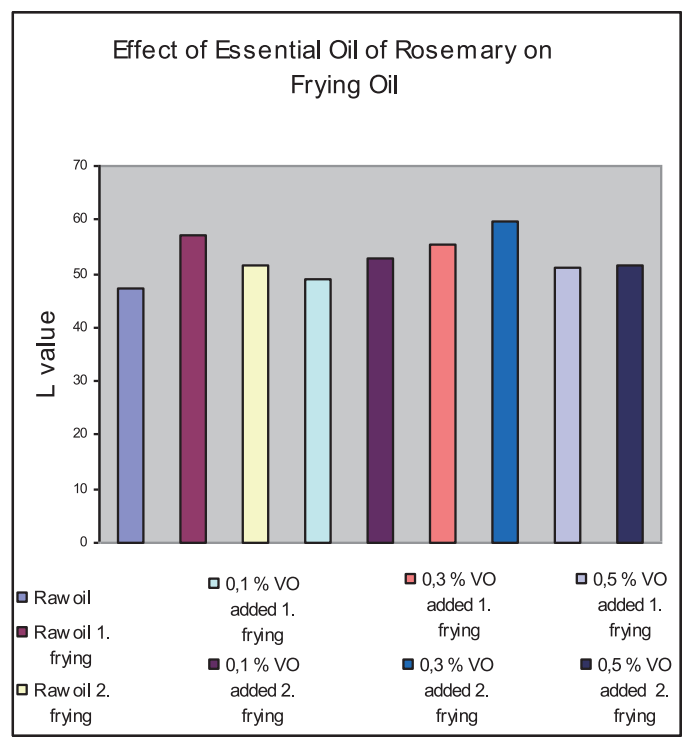

b)

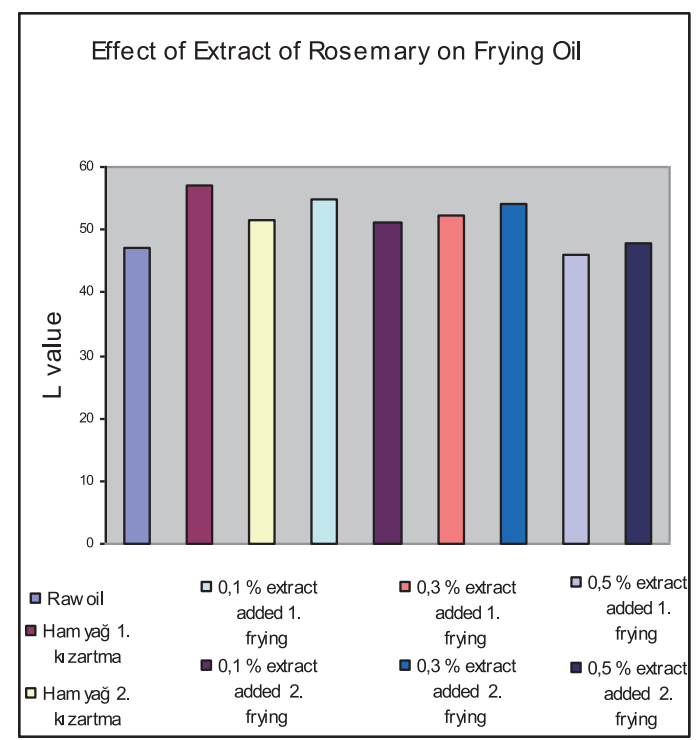

Fig. 1 (a) Action of essential oil of rosemary on $L^{*}$ value of frying oil. (b) Action of extract of rosemary on $L^{*}$ value of frying oil. 
creased ( (Fig. 1 (b). Increase in the value of $b^{*}$ of 1 . and 2 . frying oil with $0.5 \%$ rosemary essential oil was less (Fig. 3 (a) ). $b^{*}$-Value of the frying oils containing rosemary extract increased compared to $b^{*}$ values of frying oils containing essential oil (Fig. 3(b)). As seen, $b^{*}$-value of the fried oil containing the essential oil showed less increase than that of $b^{*}$-value of the fried oil containing extract. This increase can be probably due to the color of dark rosemary extract. Ulusoy and Ergin ${ }^{2}$ conducted a study conducted on oxidative stability of canola oil containing high-linolenic acid during deep frying, and measured the color of frying oil by Hunter color system.

The viscosity value (33.7 and $32.9 \mathrm{mPas}$ for 1 . and 2 . frying) of the fried raw sunflower oil decreased as a result of frying. The viscosity values of 1 . and 2 . frying made by adding $0.1 \%$ essential oil of rosemary did not show more decrease (Fig. 4(a)) $(p<0.05)$. The viscosity values of 1 . and 2 . fried oils made by adding extract at the almost all concentrations were found close to each other (Fig. 4(b)).

As shown in Fig. 5(a), FFA\% of the frying oils of 1 . and a)

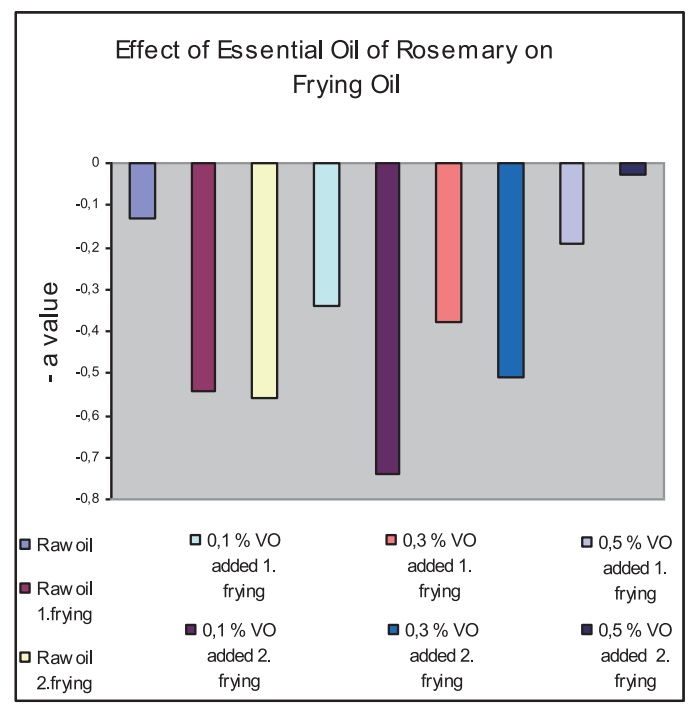

b)

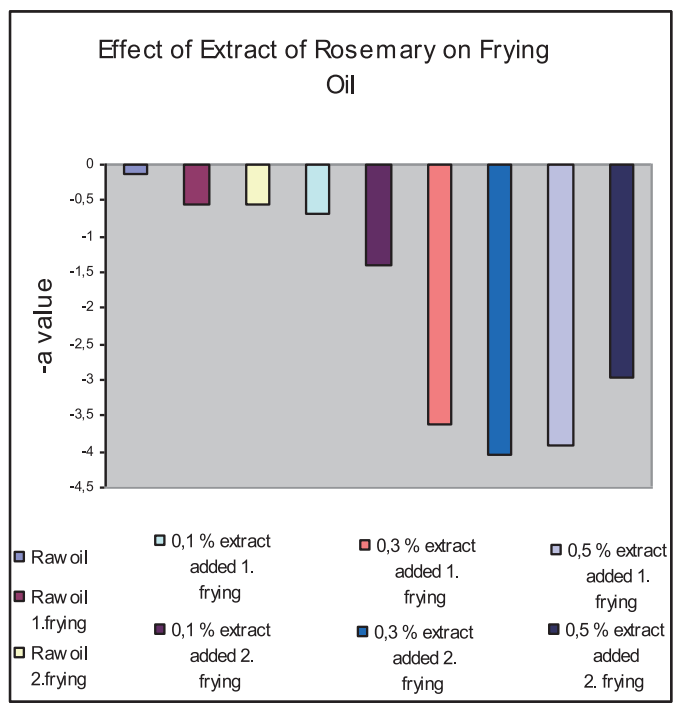

Fig. 2 (a) Action of essential oil of rosemary on $a$ value of frying oil. (b) Action of extract of rosemary on $a^{*}$ value of frying oil.

a)

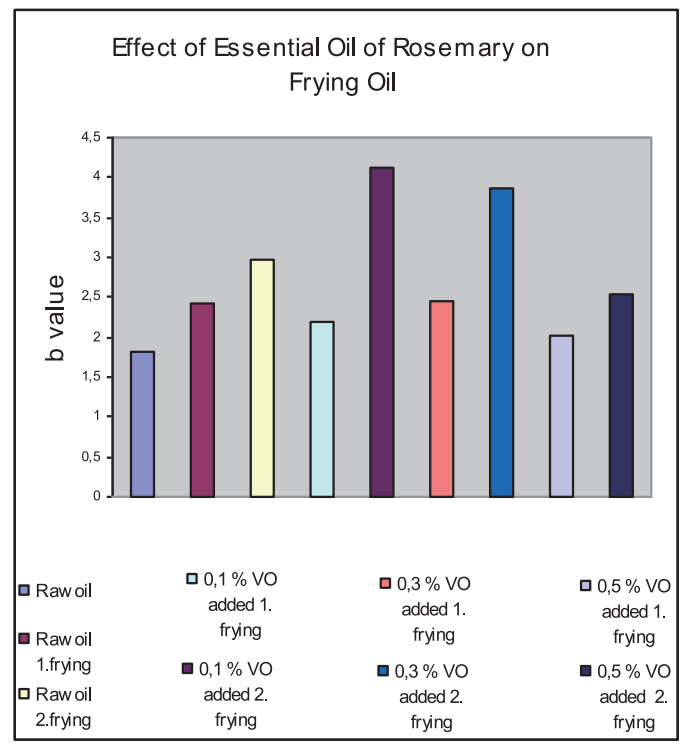

b)

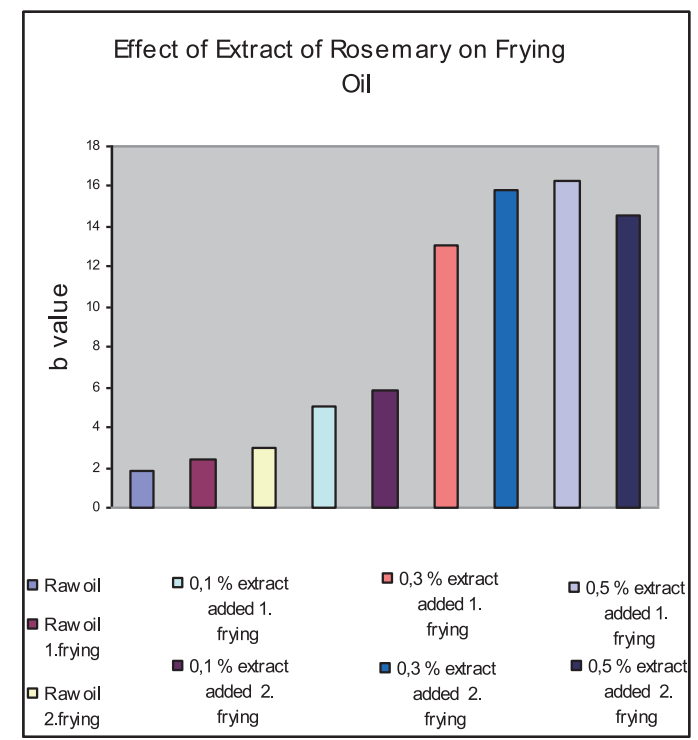

Fig. 3 (a) Action of essential oil of rosemary on $b$ value of frying oil. (b) Action of extract of rosemary on $b^{*}$ value of frying oil. 
a)

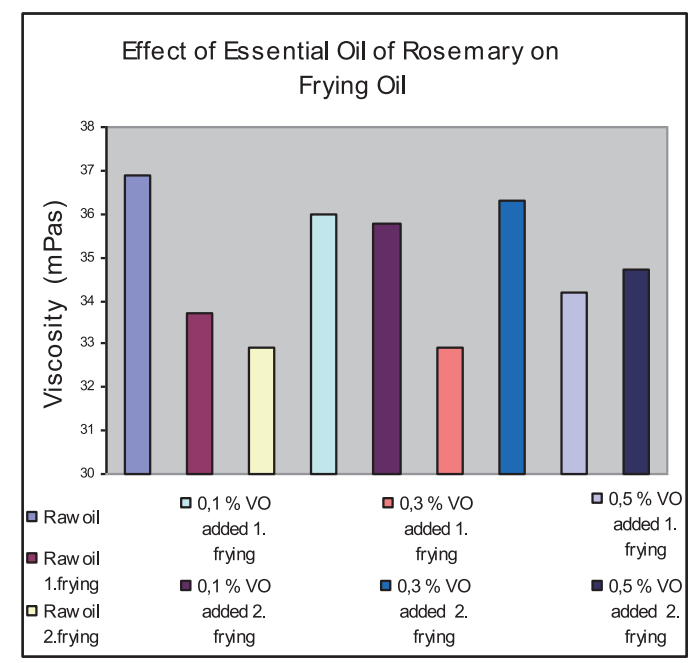

b)

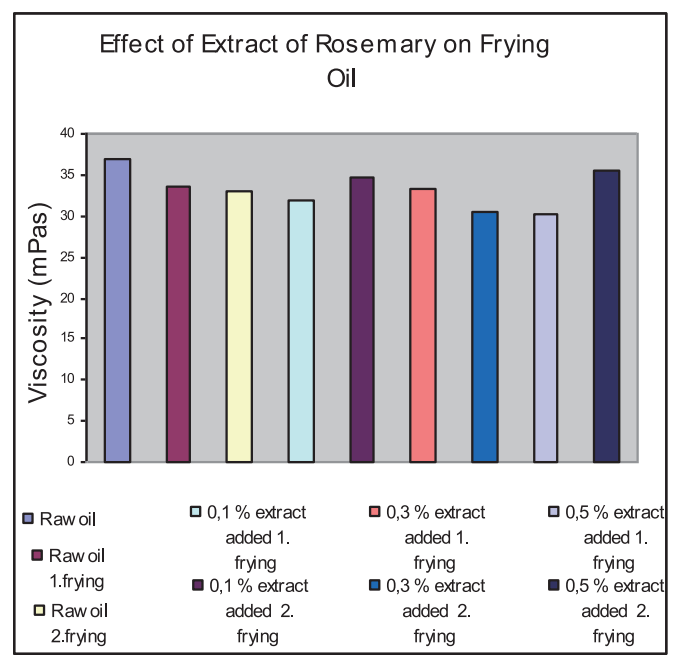

Fig. 4 (a) Action of essential oil of rosemary on viscosity of frying oil. (b) Action of extract of rosemary on viscosity of frying oil.

a)

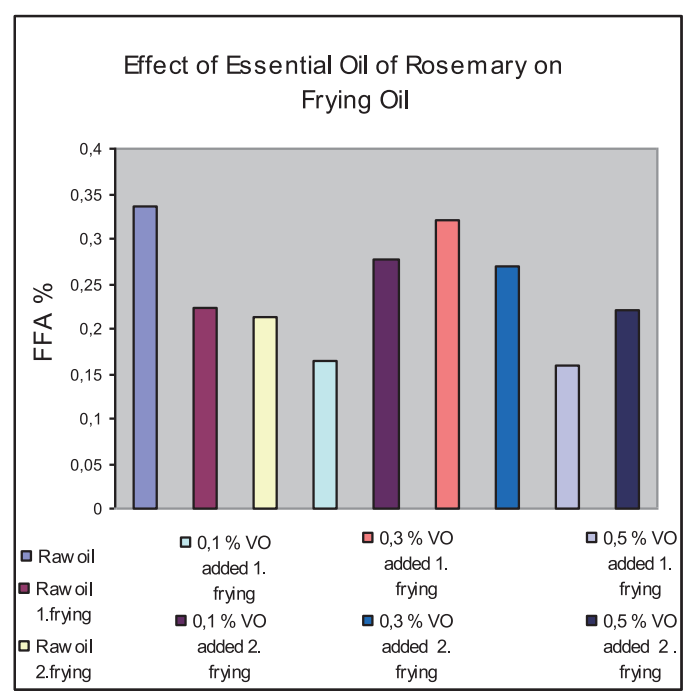

b)

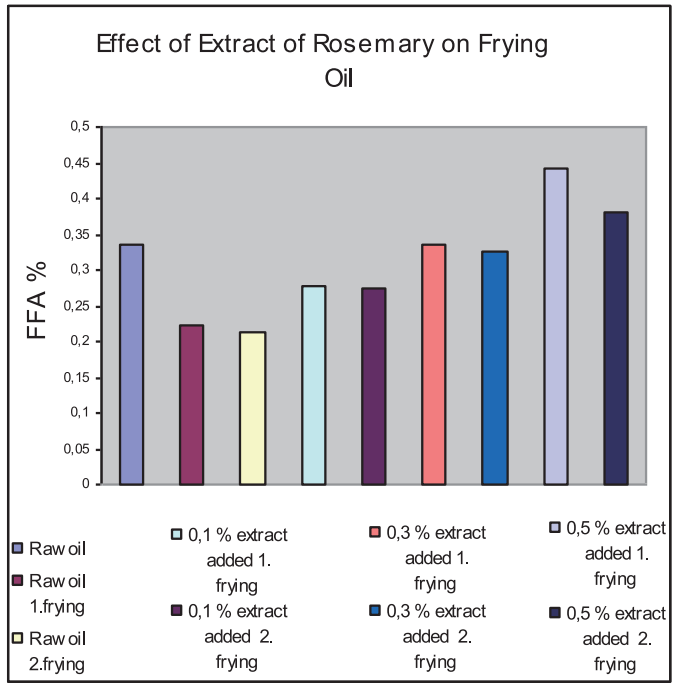

Fig. 5 (a) Action of essential oil of rosemary on FFA\% of frying oil. (b) Action of extract of rosemary on FFA\% of frying oil.

2. frying made with the sunflower oil containing $0.5 \%$ essential oil increased less than those of 1 . and 2. frying made with the raw sunflower oil. It was observed that $0.1 \%$, $0.2 \%$ and $0.3 \%$ rosemary extract had no statistically much effect on the FFA of 1st and 2nd frying oils $(p<0.05)$ (Fig. $5(\mathrm{~b}))$. The acid value can be estimated by multiplying the percent free fatty acid content expressed as oleic acid ${ }^{16,17)}$.

Peroxide value of frying made with $0.3 \%$ the rosemary essential oil increased less than that of made with the raw sunflower oil (Fig. 6(a)) $(p<0.05)$. Peroxide value of frying made with $0.5 \%$ the rosemary extract decreased (Fig. 6(b)). Whenever rosemary essential oil and rosemary extract compare, the essential oil seems to be more effec- tive on the peroxide value of the frying oil. The peroxide value is expressed in terms of milliequivalents of peroxide per $1000 \mathrm{~g}$ of sample, which oxidize potassium iodide(KI) under the conditions of the test ${ }^{17)}$. According to the study of Casal et $a l .{ }^{18)}$, peroxide values of riviera olive oil and sunflower oil after the frying process was applied for a total three hours at $170^{\circ} \mathrm{C}$ using potato were determined as 11.00 meq $\mathrm{O}_{2} / \mathrm{kg}$ and 28.00 meq $\mathrm{O}_{2} / \mathrm{kg}$, respectively. The peroxide value of hazelnut oil fried 15 times at $190^{\circ} \mathrm{C}$ for 8 min was $10.84 \mathrm{meq} \mathrm{O}_{2} / \mathrm{kg}$ while it is found to be $5.58 \mathrm{meq}$ $\mathrm{O}_{2} / \mathrm{kg}$ and 5.85 meq $\mathrm{O}_{2} / \mathrm{kg}$ in corn oil and riviera olive oil, respectively ${ }^{19)}$. As far as Ramli et $a l .{ }^{20)}$ reported that peroxide values of palm olein, sunflower and corn oils after the 
a)

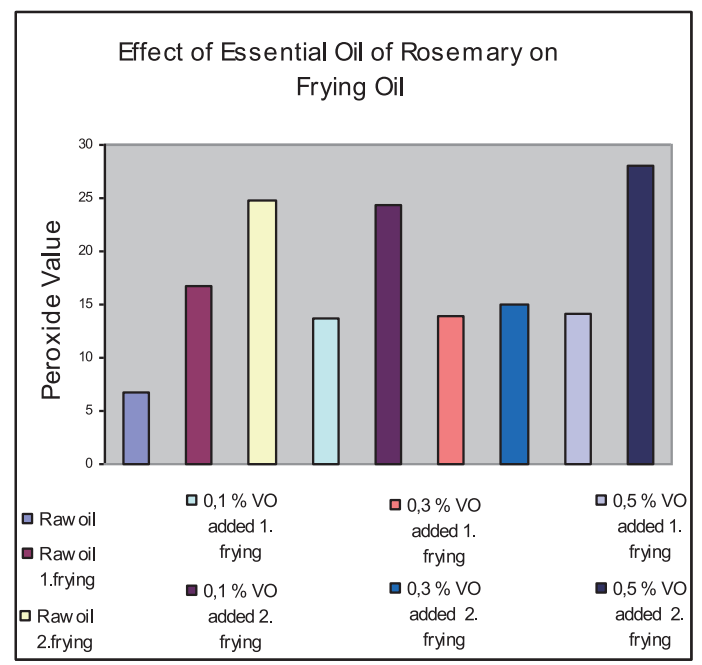

b)

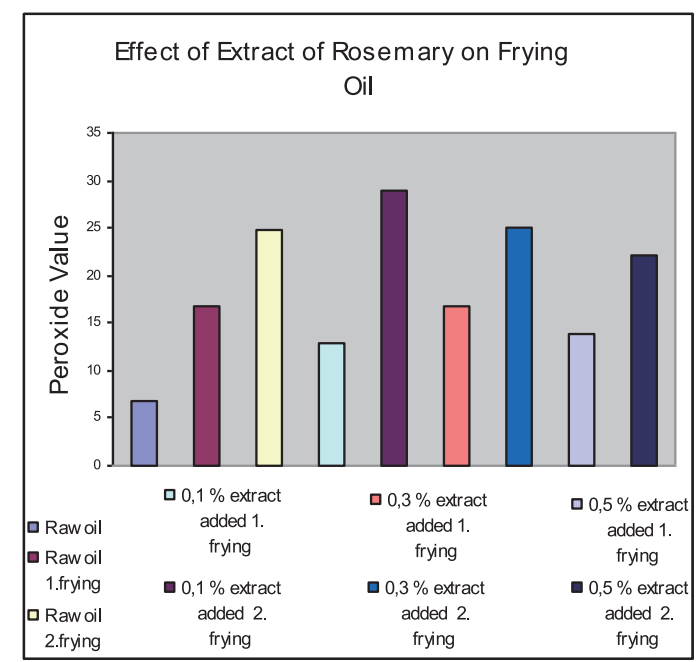

Fig. 6 (a) Action of essential oil of rosemary on peroxide value of frying oil. (b) Action of extract of rosemary on peroxide value of frying oil.

fifth potatoe frying process at $180^{\circ} \mathrm{C}$ in 2.5 min were determined as 11.66 meq $\mathrm{O}_{2} / \mathrm{kg}, 24.32$ meq $\mathrm{O}_{2} / \mathrm{kg}$ and $16.01 \mathrm{meq}$ $\mathrm{O}_{2} / \mathrm{kg}$, respectively. Levels of polar lipids in crude oils are correlated with oxidative stability ${ }^{21,22)}$. Also, a positive relationship wase determined between fatty acids and the physicochemical characteristics of the vegetable oil blends ${ }^{23)}$. In other study, progression of oxidation was followed by measuring peroxide value and $p$-anisidine value, and inverse relationships were observed between peroxide value as well as $p$-anisidine value and oxidative stability at termination of storage ${ }^{24)}$. Total phenolic content in different oils increased during frying and strongly correlated with frying time ${ }^{25)}$. Elbanna et $a l .{ }^{26)}$ rancimat test showed that blending rosemary oil with sunflower oil increased the induction period for blends. Results showed some differences with findings stated in studies made by several reseachers. These differences can be probably due to oil type, frying temperature, used additives, frying type and the type of fried materials.

\section{Conclusion}

The essential oil of rosemary have effected more from the extracts of rosemary on the oxidative stability of sunflower oil. Consequently, the frying material used did not considerably affect the viscosity, polar compounds and fatty acid compositions of oils, but the values of free fatty acids, peroxides and colors differed in respect to the fried samples. Several factors, such as oxygen, high temperature and degree of unsaturation of oils, cause various reactions in fryer oils. Accordingly, the physical, chemical and sensorial properties of oils change.

\section{Acknowledgements}

The authors would like to extend their sincere appreciation to the Deanship of Scientific Research at King Saud University for its funding the Research Group No: (RG1441-325).

\section{References}

1) Ramalho, V.C.; Jorge, N. Antioxidant action of rosemary extract in soybean oil submitted to thermoxidation. Grasas y Aceites 59, 128-131 (2008).

2) Ulusoy, B.Ö.; Ergin, G. Yüksek linolenik asitli kanola yagının derin kızartma sırasındaki oksidatif stabilitesi. Türkiye 9. Grda Kongresi, Bolu, pp. 439-442 (2006).

3) Choe, E.; Min, D.B. Chemistry of deep-fat frying oils. $J$. Food Sci. 72(5), 77-84(2007).

4) Akgül, A.; Ayar, A. Yerli baharatlarm antioksidan etkileri. Selçuk Üniversitesi Araştırma Fonu ZF 91/067, Konya, pp. 1-10 (1992).

5) Negishi, H.; Nishida, M.; Endoy, Y.; Fujimoto, K. Effect of a modified deep-fat fryer on chemical and physical characteristics of frying oil. J. Am. Oil Chem. Soc. 80, 163-166 (2003).

6) Pokorny, J. Substrate influence on the frying process. Grasas y Aceites 49, 265-270 (1998).

7) Nor, F.M.; Suhaila, M.; Aini, I.N.; Razali, I. Antioxidative properties of Murraya koenigii leaf extracts in accelerated oxidation and deep-frying studies. Int. $J$. Food Sci. Nutr. 60 (S2), 1-11(2009).

8) Anwar, F.; Ali, M.; Hussain, A.I.; Shahid, M. Antioxidant and antimicrobial activities of essential oil and extracts of fennel(Foeniculum vulgare Mill.) seeds 
from Pakistan. Flav. Fragr. J. 24, 170-176(2009).

9) Wang, D.; Dong, Y.; Wang, Q.; Wang, X.; Fan, W. Limonene, the compound in essential oil of nutmeg displayed antioxidant effect in sunflower oil during the deep-frying of Chinese Maye. Food Sci. Nutr. 8, 511520 (2019).

10) Wang, D.; Meng, Y.; Li, C.; T Li, T.; Wang, D.; Xuede Wang, X. Influence of the essential oil of Mentha spicata cv. henanshixiang on sunflower oil during the deep-frying of Chinese Maye. LWT-Food Sci. Technol. 122, (2020) (in press).

11) Criado, M.N.; Motilva, M.J.; Goni, M.; Romero, M.P. Comparative study of the effect of the maturation process of the olive fruit on the chlorophyll and carotenoid fractions of drupes and virgin oils from Arbequina and Farga cultivars. Food Chem. 2, 748-755 (2005).

13) Pagliarini, E.; Rastelli, C. Sensory and instrumental assessment of olive oil appearance. Grasas y Aceites 45, 62-64 (1994).

14) AOAC. Official Methods of Analysis, $15^{\text {th }}$ ed. Association of Official Analytical Chemists, Washington, DC (1990).

15) Püskülcü, H.; İkiz, F. Introduction Statistic(İstatistiğe Giriş). Bilgehan Press, Bornova-İzmir, Turkey p. 333 (1989). (in Turkish).

16) Bansal, G.; Zhou, W.; Barlow, P.J.; Lo, H.; Neo, F. Performance of palm olein in repeated deep frying and controlled heating processes. Food Chem. 121, 338347 (2009).

17) Spaul, S.; Mittal, G.S. Regulating the use of degraded oil/fat in deep-fat/oil food frying. Crit Rev. Food Sci. Nutr. 37, 635-662 (1997).

18) Casal, S.; Malheiro, R.; Sendas, A.; Oliveira, B.P.P.; Pereira, J.A. Olive oil stability under deep-frying conditions. Food Chem. Toxicol. 48, 2972-2979(2010).
19) Karakaya, S.; Şimşek, Ş. Changes in total polar compounds, peroxide value, total phenols and antioxidant activity of various oils used in deep fat frying. J. Am. Oil Chem. Soc. 88, 1361-1366(2011).

20) Ramli, N.; Nafar, M.; Jaswir, I. Oxidative stability of blend oil during deep-fat frying of potato chips. Pak. J. Nutr. 11 (9), 730-734(2012).

21) Ramadan, M.F.; Mörsel, J.-T. Oxidative stability of black cumin (Nigella sativa L.), coriander (Coriandrum sativum L.) and niger (Guizotia abyssinica Cass.) upon stripping. Eur. J. Lipid Sci. Technol. 106, 35-43 (2004).

22) Ramadan, M.F. Oxidation of $\beta$-sitosterol and campesterol in sunflower oil upon deep- and pan-frying of French fries. J. Food Sci. Technol. 52, 6301-6311 (2015).

23) Ramadan, M.F.; Amer, M.M.A.; Sulieman, A.R.R.M. Correlation between physicochemical analysis and radical scavenging activity of vegetable oil blends as affected by frying of French fries. Eur. J. Lipid Sci. Technol. 108, 670-678(2006).

24) Ramadan, M.F. Healthy blends of high linoleic sunflower oil with selected cold pressed oils: Functionality, stability and antioxidative characteristics. Ind. Crops Prod. 43, 65-72(2013).

25) Sharoba, A.M.; Ramadan, M.F. Rheological characteristics of vegetable oils as affected by deep frying of French fries. J. Food Meas. Charact. 8, 171-179 (2014).

26) Elbanna, K.; Assiri, A.M.A.; Tadros, M.; Khider, M., Assaeedi, A.; Mohdaly, A.A.A.; Ramadan, M.F. Rosemary (Rosmarinus officinalis) oil: Composition and functionality of the cold-pressed extract. J. Food Meas. Charact. 12, 1601-1609(2018). 